\title{
Treatment of Arctic Wastewater by Chemical Coagulation, UV and Peracetic Acid
} Disinfection

\author{
Chhetri, Ravi Kumar; Klupsch, Ewa ; Andersen, Henrik Rasmus; Jensen, Pernille Erland
}

\section{Published in:}

Environmental Science and Pollution Research

Link to article, DOI:

$10.1007 / \mathrm{s} 11356-017-8585-5$

Publication date:

2018

Document Version

Peer reviewed version

Link back to DTU Orbit

Citation (APA):

Chhetri, R. K., Klupsch, E., Andersen, H. R., \& Jensen, P. E. (2018). Treatment of Arctic Wastewater by Chemical Coagulation, UV and Peracetic Acid Disinfection. Environmental Science and Pollution Research, 25(33), 32851-32859. https://doi.org/10.1007/s11356-017-8585-5

\section{General rights}

Copyright and moral rights for the publications made accessible in the public portal are retained by the authors and/or other copyright owners and it is a condition of accessing publications that users recognise and abide by the legal requirements associated with these rights.

- Users may download and print one copy of any publication from the public portal for the purpose of private study or research.

- You may not further distribute the material or use it for any profit-making activity or commercial gain

- You may freely distribute the URL identifying the publication in the public portal 
This is a post print of the article accepted for publication $7^{\text {th }}$ February 2017 in the Environmental Science and Pollution Research. DOI: 10.1007/s11356-017-8585-5

\title{
Treatment of Arctic Wastewater by Chemical Coagulation, UV and Peracetic Acid Disinfection
}

\author{
Ravi Kumar Chhetri ${ }^{\text {a }}$, Ewa Klupsch ${ }^{\text {a,b }}$, Henrik Rasmus Andersen ${ }^{\text {a }}$, Pernille Erland Jensen ${ }^{\text {b1 }}$ \\ ${ }^{a}$ Department of Environmental Engineering, Technical University of Denmark, Bygningstorvet, Building 115, 2800 Kgs. Lyngby, \\ Denmark. \\ ${ }^{\mathrm{b}}$ Department of Civil Engineering, Technical University of Denmark, Bygningstorvet, Brovej, Building 118, 2800 Kgs. Lyngby, \\ Denmark. ${ }^{1}$ Corresponding author: pej@byg.dtu.dk
}

\begin{abstract}
Conventional wastewater treatment is challenging in the Arctic region due to the cold climate and scattered population. Thus, no wastewater treatment plant exists in Greenland and raw wastewater is discharged directly to nearby waterbodies without treatment. We investigated the efficiency of physicochemical wastewater treatment, in Kangerlussuaq, Greenland. Raw wastewater from Kangerlussuaq was treated by chemical coagulation and UV disinfection. By applying $7.5 \mathrm{mg} \mathrm{Al} / \mathrm{L}$ polyaluminium chloride (PAX XL100), 73\% of turbidity and 28\% phosphate was removed from raw wastewater. E. coli and Enterococcus were removed by 4 and $2.5 \mathrm{log}$, respectively, when UV irradiation of $0.70 \mathrm{kWh} / \mathrm{m}^{3}$ was applied to coagulated wastewater. Furthermore, coagulated raw wastewater in Denmark, which has a chemical quality similar to Greenlandic wastewater, was disinfected by peracetic acid or UV irradiation. Removal of heterotrophic bacteria by applying $6 \mathrm{mg} / \mathrm{L}$ and $12 \mathrm{mg} / \mathrm{L}$ peracetic acid was 2.8 and $3.1 \mathrm{log}$, respectively. Similarly, removal of heterotrophic bacteria by applying $0.21 \mathrm{kWh} / \mathrm{m}^{3}$ and $2.10 \mathrm{kWh} / \mathrm{m}^{3}$ for UV irradiation was 2.1 and greater than $4 \mathrm{log}$, respectively. Physico-chemical treatment of raw wastewater followed by UV irradiation and/or peracetic acid disinfection showed the potential for treatment of arctic wastewater.
\end{abstract}

KEY WORDS: coagulation, poly aluminum chloride, wastewater, disinfection, Peracetic acid, UV irradiation, arctic.

\section{Introduction}

Wastewater treatment plants are designed to protect the human health, environment and water resources by removing harmful and hazardous chemicals and bacteria from wastewater. In Greenland and many other arctic locations, neither industrial nor domestic wastewater is treated before it is discharged to the recipients, which in most cases is the sea (Gunnarsdóttir et al., 2013). Discharge of untreated wastewater may deteriorate the quality of receiving surface waters, since raw wastewater contains a variable mixture of various pathogenic organisms, pollutants, cysts, suspended solids, chemicals and floatable materials.

According to a report from the Danish EPA (Danish Environmental Protection Agency, 2005) organic matter and nutrients disposed of with blackwater to the recipients, are not of great concern in Greenland due to low population density and large receiving water bodies. However, in the case of poor water exchange, those substances can lower the quality of the marine environment and lead to eutrophication. Furthermore, pathogens can affect human health and when wastewater brings visible floating items in the vicinity of domestic areas, it may impact general life quality and also tourists experiences in the otherwise pristine country. Finally the lack of treatment may cause a potential risk towards the fishing industry due to the impacts on the receiving aqueous environment.

The Arctic has unique environmental and infrastructural conditions; therefore, construction of conventional wastewater treatment plants poses several challenges: a treatment facility, cannot be constructed with open basins due to the risk of freezing of the water during winter time; and even during periods without freezing, low average temperatures would result in significantly increased retention times and thus, basin sizes due to low biological and chemical treatment activity (Gunnarsdóttir et al., 2013). Thus, the successful solution should require little space in order to be contained in a structure protecting form the ambient conditions at lowest possible construction costs, and in addition be simple and easy to maintain for the locals in the small communities.

A main purpose of wastewater disinfection is to eliminate or inactivate disease causing microorganisms such as bacteria and viruses to protect the public health and environment. An ideal disinfectant should efficiently remove maximum pathogenic microorganisms without generating toxic and undesirable by-products and it should be inexpensive and technologically compatible (Tchobanoglous et al., 2003). Hypochlorite and 
chlorine dioxide are well known disinfectants used in the water industries (White, 2010), which could be used to reduce contamination by microorganisms from wastewater, but the by-products of these are of environmental concern (Bayo et al., 2009; Hrudey and Charrois, 2012; Nurizzo et al., 2005; Svecevicius et al., 2005; Watson et al., 2012). Ozone is a very efficient disinfectant; however, the sophisticated technology to generate ozone makes it unsuitable for disinfection of wastewater in the Arctic region.

Organic peroxide, peracetic acid (PAA) is a strong disinfectant with a wide spectrum of antimicrobial activity, which was introduced to wastewater treatment approximately 30 years ago (Antonelli et al., 2006; Baldry, 1983; Falsanisi et al., 2006; Kitis, 2004; Koivunen and Heinonen-Tanski, 2005; Luukkonen et al., 2015) and recently it has been used to disinfect combined sewer overflows (Chhetri et al., 2016, 2014). Commercial PAA is available as an acidic quaternary equilibrium mixture of PAA, hydrogen peroxide, acetic acid, and water:

$$
\mathrm{CH}_{3} \mathrm{COOH}+\mathrm{H}_{2} \mathrm{O}_{2} \rightleftharpoons \mathrm{CH}_{3} \mathrm{CO}_{3} \mathrm{H}+\mathrm{H}_{2} \mathrm{O}
$$

The residues after PAA use are acetic acid, hydrogen peroxide, and water. Acetic acid is further biodegraded to carbon dioxide, whilst hydrogen peroxide degrades to oxygen and water; neither of which are considered toxic to aquatic life (Liberti and Notarnicola, 1999).

UV irradiation is an effective disinfectant used in water industry since it kills the bacteria by damaging the DNA of bacteria. Furthermore, it shows high effectiveness in reducing bacterial resistance to chemical disinfection. UV disinfection does not produce toxic by-products compared to chemical disinfectants such as chlorine and chlorine dioxide (Svecevicius et al., 2005; USEPA, 1999; White, 2010). The effectiveness of a UV disinfection system depends on the characteristics of the wastewater, the intensity of UV radiation, the amount of time the microorganisms are exposed to the radiation, and the reactor configuration (USEPA, 1999). Generally disinfection systems based on UV lamps are made with the UV lamp being submerged in the water in a flow through reaction tank, with the lamp being separated from the water by a quarts sleeve. For water that has a high tendency to foul the quarts sleeve, a special reactor configuration known as a noncontact UV disinfection system, in which the UV radiation source is placed above the wastewater stream, exists (Tchobanoglous et al., 2003; USEPA, 1999). However, from mathematical model simulations, Kim et al. (2011) have shown that non-contact UV systems require a 2.5 times more powerful UV lamp than the conventional submerged type UV system. Considering the costs of regular cleaning and maintenance of a conventional submerged UV system in a small to middle scale wastewater treatment plant, a non-contact UV disinfection system may, however, be preferred in remote locations. Furthermore, many of the towns in Greenland are supplied by hydropower from reservoirs with higher capacity than presently needed, thus the additional energy could be sustainably supplied at low additional cost for the society.

The efficiency of disinfection can be increased if wastewater is pretreated by physical and/or chemical processes, such as chemical coagulation. The primary purpose of coagulation is to reduce suspended solids and any contaminants associated with them. Chemical coagulation is the process of the formation of flocs (large particles) from finely divided and destabilized particles. Suspended solids and other pollutants from wastewater can be removed by chemical coagulation, followed by lamella clarification; and the process is considered an essential component of wastewater treatment (Tchobanoglous et al., 2003). Chemical coagulation has been used extensively to remove suspended solids, heavy metals, COD and phosphate from wastewater and combined sewer overflows (Delporte et al., 1995; El Samrani et al., 2008; Gasperi et al., 2012; Jolis and Ahmad, 2004; Plum, 1998).

To our knowledge, there are no studies available concerning chemical coagulation and disinfection of wastewater in Greenland. Moreover, the municipality of Qeqqata in central-western Greenland decided to investigate the possibility of establishing a sewage treatment plant in Kangerlussuaq. This research investigates the possibility of implementing cheap and simple solutions for sewage treatment in Greenland and other arctic regions like Alaska and Canada.

The aim of this study was to examine the performance of chemical coagulation followed by disinfection of arctic domestic wastewater with the overall goal to achieve a satisfactory quality for discharge without negative impact on the marine environment or human health risk. The investigated methods were UV irradiation and peracetic acid disinfection with and without prior chemical coagulation. For UV irradiation a non-contact UV disinfection system was tested to avoid fouling of the UV lamp by adhesion of fats and particles from the wastewater. This study also documents the degradation kinetics of PAA in wastewater after chemical coagulation. 


\section{Materials and methods}

\subsection{Chemicals}

ABTS (2,2"-azino-bis [3-ethylbenzothiazoline-6-sulfonic acid] diammonium salt), sodium thiosulphate, and catalase from bovine liver (2000-5000 units/mg protein) were all purchased from Sigma-Aldrich (Brøndby, Denmark). All chemicals were of reagent grade. PAA (CAS no: 79-21-0) solution containing 30-40\% w/w of technical grade disinfectant was supplied by Sigma-Aldrich (Brøndby, Denmark). PAX XL 100 solution

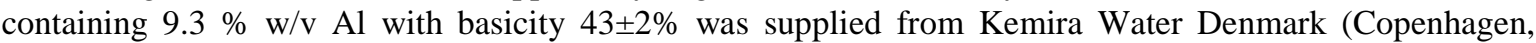
Denmark).

\subsection{Analysis}

Turbidity was measured using a Wissenschaftlich-Technische Werkstätten (WTW) turbidity meter as nephelometric turbidity units (NTU). Phosphate, and suspended solids were determined according to standard methods (APHA, 2012) and using Hach Lange test kits in the laboratory at Department of Environmental Engineering, Technical University of Denmark. PAA concentration was analyzed using the colorimetric method described by (Chhetri et al., 2014) based on selective oxidation of ABTS by PAA without interference from hydrogen peroxide.

Samples microbial analysis were processed within $2 \mathrm{~h}$ after collection. Residues of PAA were neutralized in laboratory experiments by adding $100 \mathrm{mg} / \mathrm{L}$ sodium thiosulphate to destroy PAA, followed by $50 \mathrm{mg} / \mathrm{L}$ catalase to destroy hydrogen peroxide (Wagner et al., 2002). E. coli was enumerated using Colilert-18 methods and Enterococcus were enumerated using the Enterolert methods from IDEXX (IDEXX laboratories, Maine, United States), as described by Chhetri et al. (Chhetri et al., 2014). Heterotrophic microorganisms were enumerated by using direct plate count method as described in the standard methods (APHA, 2012).

\subsection{Experimental water treatment procedures}

\subsubsection{Coagulation-flocculation test}

To find the optimal dose of the coagulant poly aluminum chloride (PAX XL100), a jar test was done. In the jar test, the coagulation process was simulated at batch scale, where a coagulant is added to destabilize the colloidal particles in wastewaters to form flocs. In short, equal volumes $(1 \mathrm{~L})$ of the raw wastewater was placed into five beakers, and mixed for one minute by rapid mixing of $120 \mathrm{rpm}$. Different concentrations of coagulant (3.5, 5.0, 7.5, 10.0, $12.5 \mathrm{mg} \mathrm{Al} / \mathrm{L}$ ) was added to each beaker and rapidly mixed for 1 additional minute. The speed was reduced to the minimum of $20 \mathrm{rpm}$ for $7 \mathrm{~min}$, to keep floc particles uniformly suspended. After the slow mixing period the paddles were removed and developed flocs were left to settle for 15 minutes. During settling, turbidity was measured after 5, 10, and 15 minutes from the supernatant withdrawn from about $25 \mathrm{~mm}$ below the surface of each beaker. After sedimentation, the supernatant was decanted carefully. For each sample, phosphate was measured before chemical coagulation and after 15 minutes of settling to assess removal. The most effective dose observed in these jar tests (i.e. inducing the greatest decrease in turbidity) was then employed to the raw wastewater.

\subsubsection{PAA disinfection}

From the stock solution, a working solution of $1 \mathrm{~g} / \mathrm{L}$ PAA was made, which was quantified daily by dilution of subsamples to $2 \mathrm{mg} / \mathrm{L}$ and analyzed using the colorimetric method described by (Chhetri et al., 2014) based on selective oxidation of ABTS by PAA without interference from hydrogen peroxide. In the experiments, three doses of PAA of 2, 6 and $12 \mathrm{mg} / \mathrm{L}$ were applied to disinfect coagulated wastewater. Concentration profiles of PAA were observed for 60 min and residual PAA was neutralized by adding sodium thiosulphate and catalase as described in section 2.2 and samples were processed for heterotrophic microorganism enumeration.

\subsubsection{UV disinfection}

In the experiments, three $7 \mathrm{~W}$ low pressure UV lamps were placed above the water surface to direct the UV radiation on the flowing wastewater (Figure 1). Both raw wastewater and coagulated wastewater were disinfected by UV irradiation by pumping a sample to an aluminum tray (length $36 \mathrm{~cm}$ width $10 \mathrm{~cm}$ ), placed in a cabin mounted with the UV lamps, allowed to flow over it, and collected on the other end in a glass beaker (Figure 1). The width and height of the disinfection chamber was $40 \mathrm{~cm}$ and $6 \mathrm{~cm}$. The distance from the UV lamp to the wastewater stream was $5 \mathrm{~cm}$ and the depth of the wastewater stream in the aluminum tray was $0.3 \mathrm{~cm}$. Experiments were conducted with four different doses of UV radiation controlled by shifting the flow speed of the wastewater stream controlled by a digital dosing pump Grundfos DME 150-4. The UV 
irradiation dose $\left(\mathrm{kWh} / \mathrm{m}^{3}\right)$ was calculated by dividing the energy used by the UV lamps by the volumetric flow of the wastewater in the disinfection chamber.

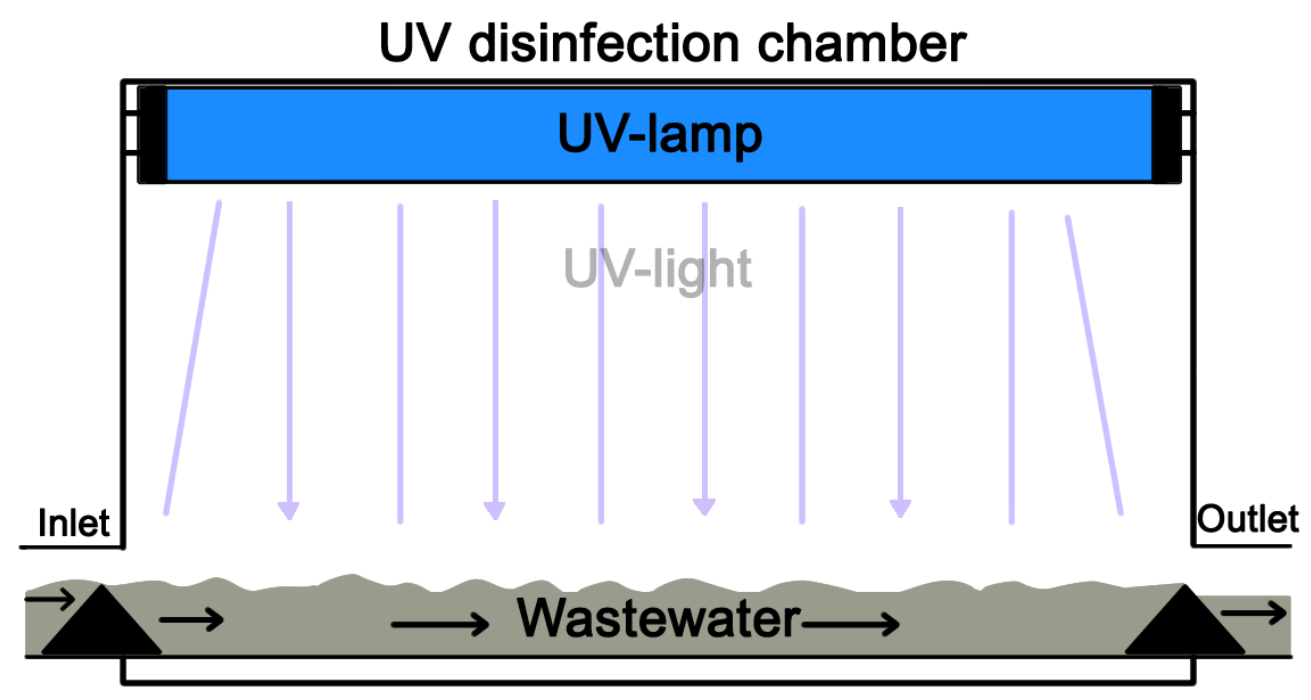

Figure 1: Schematic diagram of non-contact UV disinfection setup used for experiments.

Several experiments were performed in Denmark and Greenland and an overview of experiments performed are presented in table 1.

Table 1: Overview of experiments performed in Denmark and Greenland

\begin{tabular}{cccc}
\hline DK I & DK II & GL I & GL II \\
\hline $\mathrm{pH}$, turbidity, COD, & $\mathrm{pH}^{3-}$ turbidity, COD, & $\mathrm{pH}$, turbidity, $\mathrm{PO}_{4}{ }^{3-}$, & $\mathrm{pH}$, turbidity, $\mathrm{PO}_{4}{ }^{3-}$, \\
$\mathrm{PO}_{4}{ }^{3-}, \mathrm{NH}_{4}-\mathrm{N}$ & $\mathrm{PO}_{4}{ }^{3-}, \mathrm{NH}_{4}-\mathrm{N}$ & $\mathrm{NH}_{4}-\mathrm{N}$, conductivity & $\mathrm{NH}_{4}-\mathrm{N}$, conductivity \\
Coagulation & Coagulation & Coagulation & Coagulation \\
PAA disinfection & - & - & - \\
UV disinfection & UV disinfection & UV disinfection & UV disinfection
\end{tabular}

\subsection{Sample collection and performed experiments}

This study was conducted in batch scale in two countries: Denmark and Greenland, two experiments were conducted in each country. Experiments in Denmark were conducted to optimize the coagulation and disinfection methods for wastewater treatment in Greenland and experiments in Greenland were conducted to study the feasibility of coagulation and disinfection. For the experiments in Denmark, raw wastewater was collected on $16^{\text {th }}$ and $18^{\text {th }}$ of June 2015 from the inlet to Lundtofte wastewater treatment plant, Lundtofte, Denmark and transported to the DTU Environment laboratory within half an hour after collection. Conductivity, $\mathrm{pH}$, phosphate, $\mathrm{NO}_{3}, \mathrm{NO}_{2}$, total nitrogen, and turbidity were analyzed upon arrival.

For the experiments in Greenland, raw wastewater was collected on $8^{\text {th }}$ and $10^{\text {th }}$ of August 2015 from manholes approximately $50 \mathrm{~m}$ from the end of the wastewater discharge pipe in Kangerlussuaq. The Kangerlussuaq settlement is located in the Qeqqata municipality, Greenland, and has approximately 540 inhabitants, hosts the international airport and, as the only settlement in Greenland has a sewered network, discharging untreated wastewater into the Kangerlussuaq Fjord from two outlets. This makes Kangerlussuaq a good pilot test location for the implementation of wastewater treatment compared to the other settlements. Chemical parameters, such as $\mathrm{pH}$, conductivity, phosphate, $\mathrm{NO}_{3}, \mathrm{NO}_{2}$, total nitrogen, and turbidity, were analyzed upon arrival to the laboratory in the KISS center, Kangerlussuaq. Chemical oxygen demand (COD) and $\mathrm{NH}_{4}$ were analyzed in the DTU Environment laboratory, using frozen samples shipped from Kangerlussuaq.

In the first experiment in Denmark (DK I), raw wastewater collected from Lundtofte wastewater treatment plant was coagulated by employing jar tests using different concentrations of PAX XL 100 as described above in section 2.3.1 The coagulated wastewater was disinfected by applying PAA (2, 6 and $12 \mathrm{mg} / \mathrm{L})$ to study the disinfection efficiency and concentration profiles. In the second experiment in Denmark (DK II), raw 
wastewater was coagulated by applying a higher PAX XL 100 dose (46.5 mg Al/L) to observe the maximal removal of turbidity, phosphate, $\mathrm{COD}$ and $\mathrm{pH}$ by applying an excessive coagulant. Coagulated wastewater was disinfected by applying four doses $\left(0.21,0.30,0.53\right.$ and $\left.2.10 \mathrm{~kW} / \mathrm{m}^{3}\right)$ of $\mathrm{UV}$ irradiation by changing the flow of wastewater in the UV chamber. Heterotrophic microorganisms were enumerated from the coagulated wastewater before and after UV disinfection.

Two experiments were made in Greenland based on the experimental results from Denmark. In the first experiment (GL I), collected raw wastewater was coagulated as mentioned above in section 2.3.1. Turbidity and phosphate were measured before and after chemical coagulation to assess removal. The most effective dose observed from coagulation was then employed to the raw wastewater. The coagulated wastewater was disinfected by applying four doses $\left(0.18,0.23,0.35\right.$ and $\left.0.70 \mathrm{~kW} / \mathrm{m}^{3}\right)$ of UV irradiation and samples were processed for E. coli and Enterococcus enumeration as described above in section 2.2. In the second experiment (GL II), wastewater coagulated with $7.5 \mathrm{mg} \mathrm{Al} / \mathrm{L}$ PAX XL 100 was disinfected by applying the same dose of UV irradiation as applied in the first experiment in Greenland. E. coli and Enterococcus were enumerated from coagulated and disinfected wastewater to assess removal. Experiments could not be performed using PAA for disinfection in Greenland due to the temporary problem of having the chemical delivered to Greenland.

\section{Results and discussion}

\subsection{Chemical characteristics of wastewater before and after coagulation}

Chemical characteristics of raw wastewater from Denmark and Greenland are presented in Table 1. The turbidity of Danish wastewater was higher than Greenlandic wastewater, but the levels of ortho-phosphate in Danish wastewater were lower than in Greenlandic wastewater. However, chemical quality of single samples of wastewater from Denmark and Greenland cannot be expected to be comparable as quality of wastewater changes frequently due to the loading rate which varies at different times of the day.
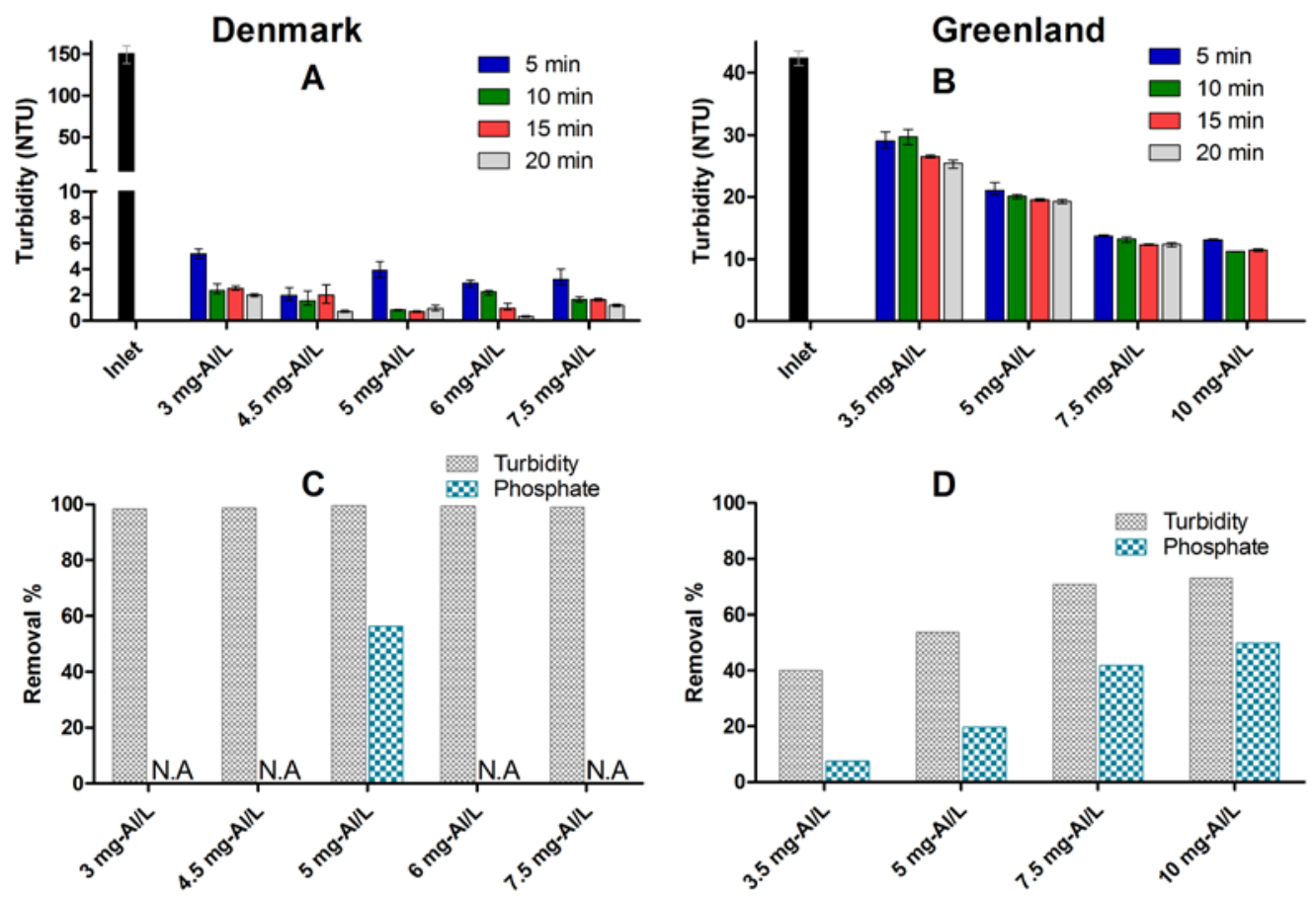

Figure 2: Effect of coagulant (PAX XL100) in Jar test on turbidity and phosphate concentrations of raw wastewater from Denmark I (graph A \& C) and Greenland I (graph B \& D). Phosphate removal from coagulated samples were measured after 15 min of sedimentation time in Jar test. T-bars in graph A \& B indicate range of measured values with turbidity. N.A stands for not analyzed.

Experiment DK I was done to optimize the coagulant dose for coagulation of wastewater which was later used for the disinfection experiment. For this, raw wastewater was coagulated using a traditional jar test and the results are presented in Figure 2 A \& C. Turbidity was reduced to 0.7 NTU from 151 NTU by applying 5 $\mathrm{mg} \mathrm{Al} / \mathrm{L}$ with 15 mins of sedimentation, whilst use of doses greater than $5 \mathrm{mg} \mathrm{Al} / \mathrm{L}$ did not show any improvements (Figure 2). Similarly, phosphate was reduced to $2.1 \mathrm{mg} / \mathrm{L}$ from $4.8 \mathrm{mg} / \mathrm{L}$ in samples coagulated 
with $5 \mathrm{mg} \mathrm{Al} / \mathrm{L}$. Based on turbidity removal $5 \mathrm{mg} \mathrm{Al} / \mathrm{L}$ was selected as an optimal coagulant dose with 15 min sedimentation time. In experiment DK II, a high coagulant dose (46.5 $\mathrm{mg} \mathrm{Al} / \mathrm{L}$ ) was applied to the raw wastewater to investigate the removal efficiency of turbidity and phosphate. Turbidity was reduced from 225 NTU to $1.1 \mathrm{NTU}$ and phosphate was removed from $6.5 \mathrm{mg} / \mathrm{L}$ to $1.1 \mathrm{mg} / \mathrm{L}$ (Table 2).

Table 2: Main characteristics of raw and coagulated wastewater from Lundtofte WWTP, Denmark and WW discharge outlet pipe, Greenland

\begin{tabular}{|c|c|c|c|c|c|c|c|c|}
\hline \multirow[b]{3}{*}{ Parameter } & \multicolumn{4}{|c|}{ Denmark } & \multicolumn{4}{|c|}{ Greenland } \\
\hline & \multicolumn{2}{|c|}{ DK I } & \multicolumn{2}{|r|}{ DK II } & \multicolumn{2}{|r|}{ GL I } & \multicolumn{2}{|r|}{ GL II } \\
\hline & $\begin{array}{l}\text { Raw } \\
\text { WW }\end{array}$ & $\begin{array}{c}\text { After } \\
\text { coagulation }^{1}\end{array}$ & $\begin{array}{l}\text { Raw } \\
\text { WW }\end{array}$ & $\begin{array}{c}\text { After } \\
\text { coagulation }^{2}\end{array}$ & $\begin{array}{l}\text { Raw } \\
\text { WW }\end{array}$ & $\begin{array}{c}\text { After } \\
\text { coagulation }^{3}\end{array}$ & $\begin{array}{l}\text { Raw } \\
\text { WW }\end{array}$ & $\begin{array}{c}\text { After } \\
\text { coagulation }^{3}\end{array}$ \\
\hline pH & 7.9 & 7.6 & 7.9 & 7.0 & 8.1 & 7.7 & 7.7 & 7.1 \\
\hline \multirow{2}{*}{$\begin{array}{c}\text { Turbidity } \\
\text { (NTU) }\end{array}$} & & & 225 & 1.1 & 42.4 & 11.4 & 97.7 & 10.4 \\
\hline & 151 & 0.7 & & & & & & \\
\hline COD (mg/L) & 268 & 69.5 & 563 & 133 & N.A & N.A & N.A & N.A \\
\hline $\mathrm{PO}_{4}{ }^{3-}(\mathrm{mg} / \mathrm{L})$ & 4.8 & 2.1 & 6.5 & 0.3 & 13.2 & 9.5 & 14.2 & $<5$ \\
\hline $\begin{array}{c}\mathrm{NH}_{4}- \\
\mathrm{N}(\mathrm{mg} / \mathrm{L})\end{array}$ & 42.3 & 40 & 60.2 & N.A & N.A & N.A & N.A & N.A \\
\hline $\begin{array}{c}\text { Conductivity } \\
(\mu \mathrm{s} / \mathrm{cm})\end{array}$ & N.A & N.A & N.A & N.A & 637 & 670 & 515 & 484 \\
\hline
\end{tabular}

N.A=Not analyzed

${ }^{1}$ PAX XL 100: $5 \mathrm{mg} \mathrm{Al} / \mathrm{L}, 15$ min sedimentation time

${ }^{2}$ PAX XL 100: $46.5 \mathrm{mg} \mathrm{Al} / \mathrm{L}, 15$ min sedimentation time

${ }^{3}$ PAX XL 100: $7.5 \mathrm{mg} \mathrm{Al} / \mathrm{L}, 15$ min sedimentation time

For the experiment GL I, samples were collected after a rainy night. Due to the low turbidity it was suspected that a greater part of the discharged water came from a tank at the airport, intended for collecting the rainfall from the airport apron. An experiment was performed to optimize the coagulant dose (Figure 2 B \& D) as mentioned in section 2.3.1. The raw wastewater was coagulated by applying $7.5 \mathrm{mg}$ Al/L PAX XL 100 with 15 min sedimentation time, optimized coagulant dose, and, based on the results presented in Table 2, the removals of turbidity and ortho-phosphate were $73 \%$ and $28 \%$, respectively.

For the experiment GL II, raw wastewater was coagulated by applying optimal dose of coagulant, (7.5 mg $\mathrm{Al} / \mathrm{L}$ PAX XL 100), and turbidity and phosphate removal results are presented in table 2. Removal of phosphate was greater than $66 \%$ and turbidity was $89 \%$. Phosphate measurements below 5 mg/L were uncertain since the measuring range of the phosphate kit was 5-60 mg/L.

\subsection{Concentration profile of PAA}

PAA degradation in coagulated wastewater was observed by applying different concentrations of PAA and observing concentrations for up to $60 \mathrm{~min}$. An apparent high initial consumption of PAA was observed in all samples (Figure 3) with initial consumption of PAA increasing with increased nominal PAA dose. Thus, the initial consumption of PAA was $4.4 \mathrm{mg} / \mathrm{L}$ when $12 \mathrm{mg} / \mathrm{L}$ PAA was used; whereas the initial consumption was observed as $2.9 \mathrm{mg} / \mathrm{L}$ by applying the $6 \mathrm{mg} / \mathrm{L}$ of PAA to disinfect the wastewater pretreated with the chemical coagulation (5 mg Al/L; 15 min sedimentation time) (Figure 3) in experiment DK I. First order degradation kinetics did not fit the observed data, due to the considerable initial consumption of oxidants. To address the initial consumption of PAA, a modified first order kinetics expression was applied (Antonelli et al., 2006; Chhetri et al., 2016; Falsanisi et al., 2006) to model the concentration profile of PAA in wastewater effluents, including a parameter describing initial oxidant consumption as described by Haas and Finch (Haas and Finch, 2001):

$$
C_{t}=\left(C_{0}-C_{\text {initial }}\right) \times e^{-k t} \quad \text { (equation 2) }
$$


Rapid degradation of PAA was observed in the wastewater pretreated by PAX XL 100 and almost all PAA was degraded within 60 min except for the highest dose of $12 \mathrm{mg} / \mathrm{L}$ PAA. We previously observed rapid degradation of PAA in combined sewer overflow, however, only when it was not pretreated with PAX XL 100 (Chhetri et al., 2016). High initial consumption and faster degradation of PAA was observed in the current study and this might be due to the reaction of PAA with organic matter in the coagulated wastewater.

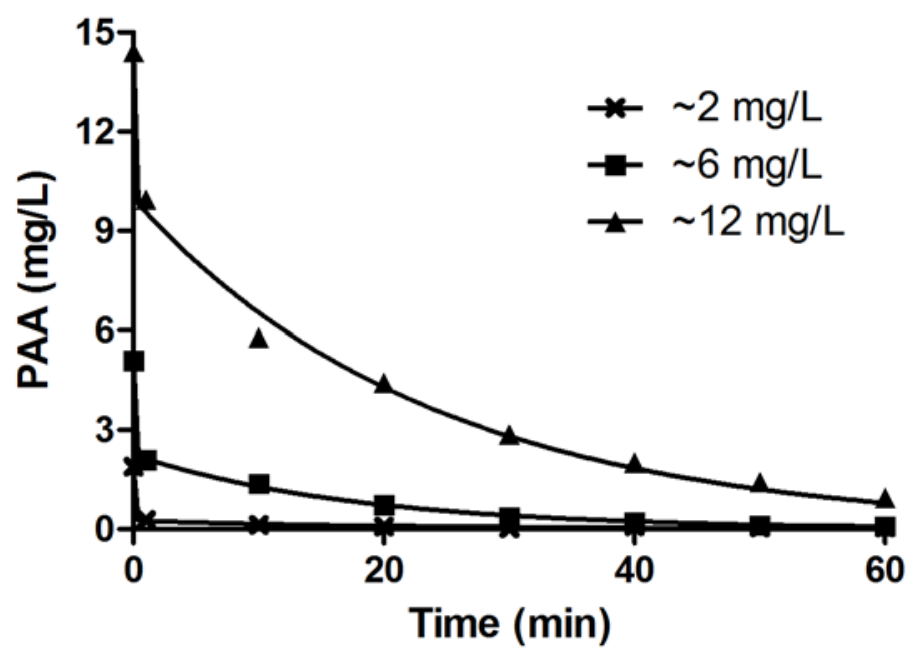

Figure 3: Concentration profile of different levels of PAA in the coagulated wastewater until 60. Curve was fitted using modified first order degradation kinetics using Equation 2.

\subsection{Disinfection efficiency}

During coagulation of raw wastewater, in addition to suspended solids, other contaminants and bacteria associated with suspended solids are also removed. Removal of bacteria from wastewater was dependent on the coagulant dose applied, removal of heterotrophic bacteria was 2.5 log when the high coagulant dose (46.5 $\mathrm{mg} \mathrm{Al} / \mathrm{L}$ ) was applied whilst removal of heterotrophic bacteria was 0.6 log when the low coagulant dose (7.5 $\mathrm{mg} \mathrm{Al} / \mathrm{L}$ ) was applied to wastewater in the coagulation experiment. Removal of bacteria was not sufficient by coagulation alone to protect the surface water from containing unacceptable high concentrations of pathogenic bacteria.

Results of microbial analysis after experiment DK I, where PAA was used as disinfectant are presented in Figure $4 \mathrm{~A}$. The initial concentrations of heterotrophic bacteria were measured as $10^{7.6} \mathrm{CFU} / \mathrm{ml}$, whilst observed concentrations after disinfection with $6 \mathrm{mg} / \mathrm{L}$ and $12 \mathrm{mg} / \mathrm{L}$ PAA with $60 \mathrm{~min}$ contact time were $10^{4.8}$ $\mathrm{CFU} / \mathrm{ml}$ and $10^{4.5} \mathrm{CFU} / \mathrm{ml}$, respectively. However, the observed concentration of heterotrophic bacteria was $10^{7.1} \mathrm{CFU} / \mathrm{mL}$ after disinfection with $2 \mathrm{mg} / \mathrm{L}$ PAA due to the rapid consumption of PAA in the coagulated wastewater (Figure 3). PAA showed promising results for removal of heterotrophic bacteria from coagulated wastewater compare to the removal of Enterococcus (2.2 log) from PAX XL 100 pre-treated combined sewer overflows (diluted wastewater by rain water) disinfected by $6 \mathrm{mg} / \mathrm{L} \mathrm{PAA}$ at $60 \mathrm{~min}$ of contact time (Chhetri et al., 2016).

The results of UV treatment of Danish wastewater are shown in figure 4B. The initial concentration of heterotrophic bacteria in the raw wastewater was $10^{7,9} \mathrm{CFU} / \mathrm{mL}$, which was reduced to $10^{5,4} \mathrm{CFU} / \mathrm{mL}$ when it was coagulated (46.5 mg AL/L PAX XL 100; sedimentation time $15 \mathrm{~min}$ ). By the higher UV dose (2.10 $\left.\mathrm{kWh} / \mathrm{m}^{3}\right)$ complete removal of heterotrophic bacteria $(<1 \mathrm{CFU} / \mathrm{mL})$ was achieved from coagulated wastewater, whilst by applying the lowest UV dose $\left(0.21 \mathrm{kWh} / \mathrm{m}^{3}\right)$ studied the heterotrophic bacteria were reduced from $10^{5,8} \mathrm{CFU} / \mathrm{mL}$ to $10^{3,2} \mathrm{CFU} / \mathrm{mL}$. From the Greenlandic wastewater (Figures $4 \mathrm{C} \mathrm{\&} \mathrm{D)} \mathrm{the} \mathrm{removal} \mathrm{of} \mathrm{E.} \mathrm{coli}$ was $0.6 \log$ and no reduction on Enterococcus was observed by coagulation. When the highest UV dose studied $\left(0.70 \mathrm{kWh} / \mathrm{m}^{3}\right)$ was applied, the removal of E. coli and Enterococcus from coagulated wastewater was 4.1 and 2.5 logs respectively; for the raw wastewater the results were 2.7 and 2.6 logs respectively. The final concentration of E. coli and Enterococcus after coagulation and UV disinfection $\left(0.70 \mathrm{kWh} / \mathrm{m}^{3}\right) \mathrm{met}$ microbial criteria for recreational purposes as described in EU bathing water directives (500 MPN E. coli and 
200 MPN Enterococcus per $100 \mathrm{~mL}$ of water) (Directive 2006/7/EC, 2006). In both experiments, higher removal of E. coli and Enterococcus was achieved by UV disinfection when samples were pretreated with chemical coagulation (Figure 4) whereas removal of E. coli and Enterococcus from raw wastewater by UV disinfection was not sufficient to achieve good microbial water quality as described in EU bathing water directives. In this study, the removal of E. coli from chemically coagulated wastewater by non-contact UV disinfection was higher than what was obtained in another study by a conventional submerged UV system to disinfect biologically treated wastewater (De Sanctis et al., 2016). Thus the non-contact UV disinfection showed potent results on removal of bacteria from wastewater in small arctic communities where biological treatment is not feasible and maintenance operations should be reduced, despite the higher energy costs.

A

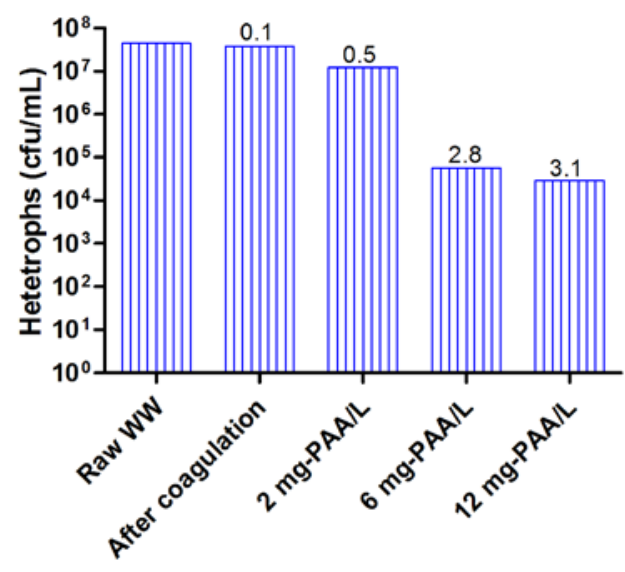

C

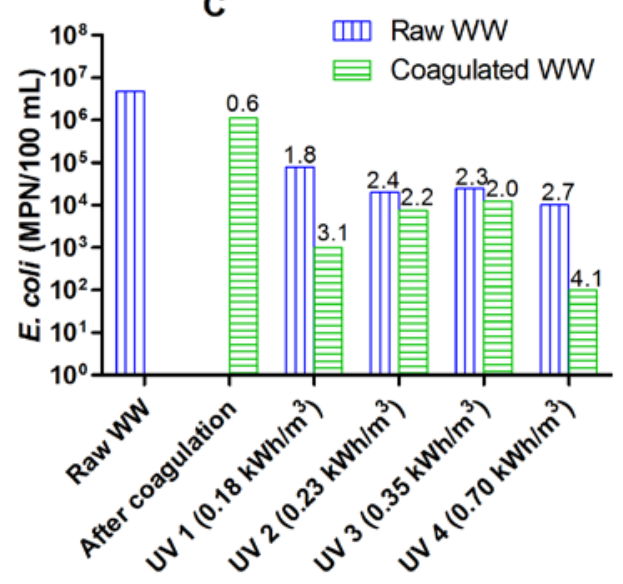

E

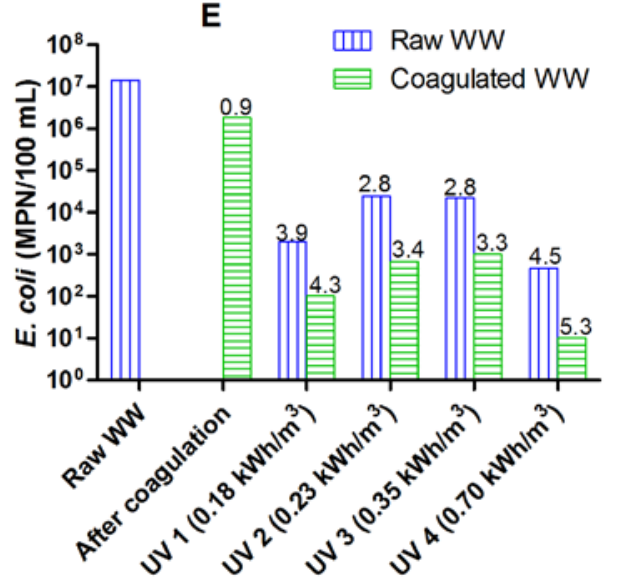

B

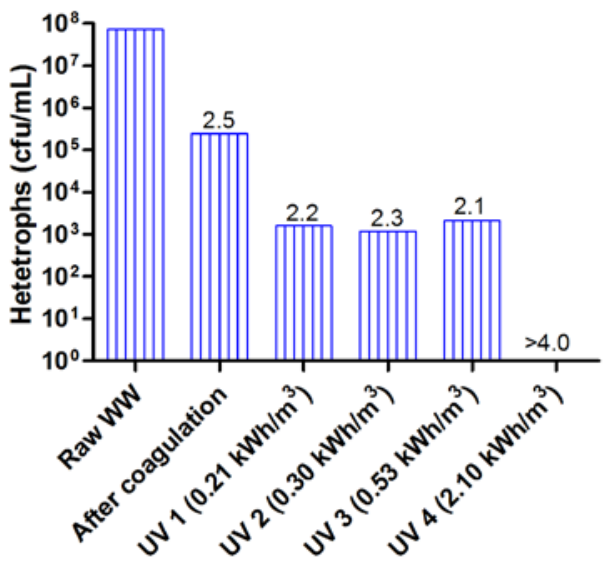

D

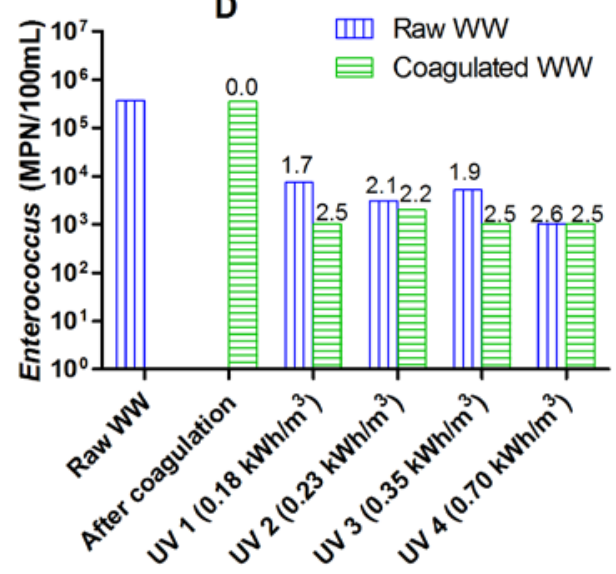

$\mathbf{F}$

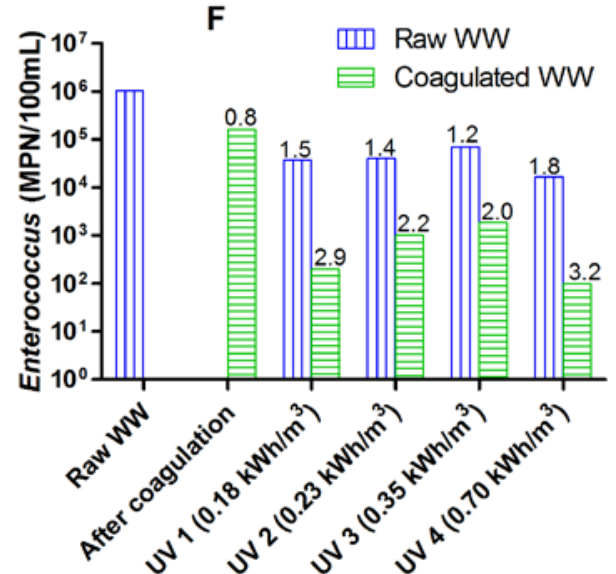

Figure 4: A) Removal of heterotrophic bacteria from raw wastewater treated with chemical coagulation and PAA disinfection from experiment DK I, B) removal of heterotrophic bacteria from raw wastewater treated with chemical coagulation and UV irradiation from experiment DK II, C, D, E \& F) removal of E. coli and Enterococcus from raw 
wastewater treated with chemical coagulation and UV irradiation from experiments GL I (C, D) and II (E, F). Numbers above bars in the graphs represent the log10 removal of microorganisms after chemical coagulation and disinfection. Log reduction on UV irradiation was calculated from "after coagulation" bar.

\section{Conclusion}

Heterotrophic bacteria, E. coli and Enterococcus can be removed from raw wastewater by combination of chemical coagulation followed by either chemical disinfection by PAA or by non-contact UV irradiation, while non-contact UV irradiation of raw wastewater is not sufficient on its own. Complete bacteria removal was reached by combination of PAX XL100 and UV disinfection at a high dose $\left(2.10 \mathrm{kWh} / \mathrm{m}^{3}\right)$. Furthermore, optimized coagulation dose effectively removed the suspended solids and chemical contaminants associated with it.

In summary, a combined treatment of chemical coagulation and non-contact UV irradiation or PAA disinfection offers a logistically feasible solution for small arctic settlements, capable of significantly mitigating negative effects of wastewater on receiving surface waters bodies and human health. Thus, this method could be a possible solution for the wastewater treatment in Kangerlussuaq and other settlements in the Arctic region.

\section{Acknowledgements}

Authors gratefully acknowledge the support of Qeqqata Municipality and the Government of Greenland who financed the field study in Kangerlussuaq, Greenland.

\section{References}

Antonelli, M., Rossi, S., Mezzanotte, V., Nurizzo, C., 2006. Secondary effluent disinfection: PAA long term efficiency. Environ. Sci. Technol. 40, 4771-4775. doi:10.1021/es060273f

APHA, 2012. Standard Methods for the Examination of water and wastewater (22nd Edition). American Public Health Association /American Water Works Association/Water Environment Federation, Washington DC, USA.

Baldry, M.G.C., 1983. The bactericidal, fungicidal and sporicidal properties of hydrogen peroxide and peracetic acid. J. Appl. Bacteriol. 54, 417-423.

Bayo, J., Angosto, J.M., Gómez-López, M.D., 2009. Ecotoxicological screening of reclaimed disinfected wastewater by Vibrio fischeri bioassay after a chlorination-dechlorination process. J. Hazard. Mater. 172, 166-171. doi:10.1016/j.jhazmat.2009.06.157

Chhetri, R.K., Bonnerup, A., Andersen, H.R., 2016. Combined Sewer Overflow pretreatment with chemical coagulation and a particle settler for improved peracetic acid disinfection. J. Ind. Eng. Chem. 37, 372-379. doi:10.1016/j.jiec.2016.03.049

Chhetri, R.K., Thornberg, D., Berner, J., Gramstad, R., Ojstedt, U., Sharma, A.K., Andersen, H.R., 2014. Chemical disinfection of combined sewer overflow waters using performic acid or peracetic acids. Sci. Total Environ. 490, 1065-1072. doi:10.1016/j.scitotenv.2014.05.079

Danish Environmental Protection Agency, 2005. Udrednings- og pilotprojekt vedr. håndtering af miljøproblemer som følge af spildevand i de grønlandske byer. Fase 2 Katalog over tekniske løsningsmuligheder (Danish report, written by the engineering firm COWI for the Danish Environmental Agency).

De Sanctis, M., Del Moro, G., Levantesi, C., Luprano, M.L., Di laconi, C., 2016. Integration of an innovative biological treatment with physical or chemical disinfection for wastewater reuse. Sci. Total Environ. 543, 206-213. doi:10.1016/j.scitotenv.2015.11.006

Delporte, C., Pujol, R., Vion, P., 1995. Optimized lamellae settling for urban stormwater waste. Water Sci. Technol. 32, 127-136.

Directive 2006/7/EC, 2006, 2006. European bathing water directive. Official Journal of the European Union L64, 37-51. 
El Samrani, A.G., Lartiges, B.S., Villiéras, F., 2008. Chemical coagulation of combined sewer overflow: Heavy metal removal and treatment optimization. Water Res. 42, 951-960. doi:10.1016/j.watres.2007.09.009

Falsanisi, D., Gehr, R., Santoro, D., Dell'Erba, A., Notarnicola, M., Liberti, L., 2006. Kinetics of PAA demand and its implications on disinfection of wastewaters. Water Qual. Res. J. Canada 41, 398-409.

Gasperi, J., Laborie, B., Rocher, V., 2012. Treatment of combined sewer overflows by ballasted flocculation: Removal study of a large broad spectrum of pollutants. Chem. Eng. J. 211-212, 293-301. doi:10.1016/j.cej.2012.09.025

Gunnarsdóttir, R., Jenssen, P.D., Erland Jensen, P., Villumsen, A., Kallenborn, R., 2013. A review of wastewater handling in the Arctic with special reference to pharmaceuticals and personal care products (PPCPs) and microbial pollution. Ecol. Eng. 50, 76-85. doi:10.1016/j.ecoleng.2012.04.025

Hrudey, S.E., Charrois, W.J., 2012. Disinfection By-products and Human Health. IWA Publishing, London United Kingdom.

Haas, C.N., Finch, G.R., 2001. Methodologies for the Determination of Disinfection Effectiveness. American Water Works Association Research Foundation, Denver, Colorado, USA.

Jolis, D., Ahmad, M.-L., 2004. Evaluation of High-Rate Clarification for Wet-Weather-Only Treatment Facilities. Water Environ. Res. 76, 474-480. doi:10.2175/106143004X151563

Kim, S.H., Choi, Y.G., Kim, D., 2011. Development of UV Distribution Model for the Non-Contact Type UV Disinfection System. Int. J. Chem. React. Eng. 9. doi:10.1515/1542-6580.2639

Kitis, M., 2004. Disinfection of wastewater with peracetic acid: A review. Environ. Int. 30, 47-55. doi:10.1016/S01604120(03)00147-8

Koivunen, J., Heinonen-Tanski, H., 2005. Peracetic acid (PAA) disinfection of primary, secondary and tertiary treated municipal wastewaters. Water Res. 39, 4445-4453. doi:10.1016/j.watres.2005.08.016

Liberti, L., Notarnicola, M., 1999. Advanced treatment and disinfection for municipal wastewater reuse in agriculture. Water Sci. Technol. 40, 235-245. doi:10.1016/S0273-1223(99)00505-3

Luukkonen, T., Heyninck, T., Rämö, J., Lassi, U., 2015. Comparison of organic peracids in wastewater treatment: Disinfection, oxidation and corrosion. Water Res. 85, 275-285. doi:10.1016/j.watres.2015.08.037

Nurizzo, C., Antonelli, M., Profaizer, M., Romele, L., 2005. By-products in surface and reclaimed water disinfected with various agents. Desalination 176, 241-253. doi:10.1016/j.desal.2004.11.012

Plum, V., 1998. The Actiflo method. Water Sci. Technol. 37, 269-275. doi:10.1016/S0273-1223(97)00778-6

Svecevicius, G., Šyvokiene, J., Stasiunaite, P., Mickeniene, L., Syvokiene, J., Stasiŭnaite, P., 2005. Acute and chronic toxicity of chlorine dioxide ( $\mathrm{ClO} 2)$ and chlorite (ClO2-) to rainbow trout (Oncorhynchus mykiss). Environ. Sci. Pollut. Res. 12, 302-305. doi:10.1065/espr2005.04.248

Tchobanoglous, G., Burton, F.L., Stensel, H.D., 2003. Wastewater Engineering, Treatment and Reuse. Metcalf \& Eddy Inc., 4th ed. McGraw Hill, New York.

USEPA, 1999. Wastewater technology fact sheet, Ultraviolet disinfection.

Wagner, M., Brumelis, D., Gehr, R., 2002. Disinfection of Wastewater by Hydrogen Peroxide or Peracetic Acid : Development of Procedures for Measurement of Residual Disinfectant and Application to a Physicochemically Treated Municipal Effluent. Water Environ. Res. 74, 33-50.

Watson, K., Shaw, G., Leusch, F.D.L., Knight, N.L., 2012. Chlorine disinfection by-products in wastewater effluent: Bioassay-based assessment of toxicological impact. Water Res. 46, 6069-6083. doi:10.1016/j.watres.2012.08.026

White, G.C., 2010. Handbook of chlorination and alternative disinfectants, 5th ed. John Wiley \& Sons, Inc., New York. 